\title{
PERBANDINGAN KADAR KALIUM DARAH SEBELUM DAN SESUDAH AKTIVITAS FISIK INTENSITAS BERAT
}

\author{
Ronald J. Pokneangge \\ Murniati Tiho \\ Yanti M. Mewo
}

\begin{abstract}
Kandidat Skripsi Fakultas Kedokteran Universitas Sam Ratulangi Manado Bagian Biokimia Fakultas Kedokteran Universitas Sam Ratulangi Manado Email: pokneangger@yahoo.com
\end{abstract}

\begin{abstract}
Physical activities include all body movements ranging from a small movement to a movement that involves several large muscles such as lifting the arms and legs. During a physical activity, the body temperature will increase, and as a compensatory mechanism, the body will sweat and release several kinds of electrolyte such as magnesium, sodium, and potassium. Potassium is a macronutrient that is widely available in the intracellular fluid (ICF). The normal value of serum potassium is $3.5-5.0 \mathrm{mmol} / \mathrm{L}$. This study aimed to obtain the comparison of blood potassium levels of fourth year students of the Faculty of Medicine, University of Sam Ratulangi Manado, before and after vigorous physical activities. This was an experimental study with a one group pretest-posttest design. There were 21 male students as respondents obtained by using the simple random sampling method. Data were analyzed by using the paired t-test. The physical activity conducted was playing futsal for $2 \times 20$ minutes with a break of 10 minutes in between. The results showed that the average of serum potassium level before doing the physical activity was $3.7 \mathrm{mmol} / \mathrm{L}$, and the average of the serum potassium level after doing physical activity was $3.8 \mathrm{mmol} / \mathrm{L}$. The paired t-test showed a p value of 0.061 ( $>0.05)$. Conclusion: There was no significant difference between serum potassium levels before and after vigorous physical activity,
\end{abstract}

Keywords: potassium, physical activity, vigorous intensity

\begin{abstract}
Abstrak: Aktivitas fisik meliputi semua gerakan tubuh mulai dari gerakan kecil sampai gerakan yang melibatkan pergerakan beberapa otot besar seperti saat mengangkat lengan atau tungkai. Ketika melakukan aktivitas fisik, terjadi peningkatan suhu tubuh dan sebagai mekanisme kompensasinya tubuh akan mengeluarkan keringat dan beberapa jenis elektrolit misalnya magnesium, natrium dan kalium. Kalium merupakan salah satu makronutrien yang banyak terdapat dalam cairan intrasel (CIS). Nilai normal kalium serum yaitu 3,5-5,0 mmol/L. Penelitian ini bertujuan untuk mengetahui perbandingan kadar kalium darah sebelum dan sesudah aktivitas fisik intensitas berat pada mahasiswa Fakultas Kedokteran Universitas Sam Ratulangi Manado angkatan tahun 2011. Jenis penelitian ini eksperimental dengan rancangan one group pretest-posttest design. Responden diperoleh menggunakan metode simple random sampling. Hasil pengukuran kadar kalium serum sebelum dan sesudah aktivitas fisik intensitas berat dianalisis menggunakan uji paired t-test. Aktivitas fisik yang dilakukan yaitu bermain futsal selama 2x20 menit dengan diselingi istirahat selama 10 menit. Hasil penelitian memperlihatkan dari 21 responden (laki-laki) rerata kadar kalium serum sebelum melakukan latihan fisik 3,7 mmol/L, dan rerata kadar kalium serum sesudah melakukan latihan fisik 3,8 $\mathrm{mmol} / \mathrm{L}$. Uji paired t test menunjukkan nilai $\mathrm{p}=0,061(\mathrm{p}>0,05)$. Simpulan: Tidak terdapat perbedaan bermakna antara kadar kalium serum sebelum dan sesudah latihan fisik intensitas berat.
\end{abstract}

Kata kunci: kalium, aktivitas fisik, intensitas berat 
Sehat menurut World Health Organisation (WHO) merupakan suatu keadaan kondisi fisik, mental dan kesejahteraan sosial yang merupakan satu kesatuan dan bukan hanya bebas dari penyakit kecacatan. Begitu banyak cara yang dapat dilakukan seseorang untuk menjaga kondisi tubuh tetap sehat, salah satunya yaitu dengan cara melakukan aktivitas fisik. ${ }^{1}$

Aktivitas fisik merupakan perilaku manusia yang kompleks.Secara teoritis aktivitas fisik meliputi semua gerakan tubuh mulai dari gerakan kecil sampai gerakan yang melibatkan gerakan beberapa otot besar seperti terjadi ketika menggerakkan lengan dan tungkai. Pada umumnya aktivitas diartikan sebagai gerakan tubuh yang ditimbulkan oleh otot-otot skelet dan mengakibatkan pengeluaran energi. Untuk menilai aktivitas fisik ada empat dimensi yang menjadi fokus yaitu tipe, frekuensi, durasi dan intensitas. ${ }^{2}$

Ketika melakukan aktivitas fisik, tubuh akan mengalami peningkatan panas dan sebagai mekanisme kompensasi tubuh akan mengeluarkan keringat yang disertai dengan elektrolit. Semakin berat aktivitas fisik yang dilakukan seseorang, semakin banyak juga keringat atau elektrolit yang dikeluarkan; hal ini yang dapat menyebabkan kadar beberapa anion dan kation dalam tubuh mengalami penurunan, salah satunya yaitu kalium. ${ }^{3,4}$

Kalium merupakan unsur kimia dari kelompok logam alkali dengan simbol $\mathrm{K}^{+}$ pada tabel periodik, memiliki nomor atom 19 dan massa atom standar 39.098. Kalium merupakan salah satu zat yang paling banyak ditemukan dalam cairan intrasel dengan jumlah $140 \mathrm{mmol} / \mathrm{L}$ dan 4 $\mathrm{mmol} / \mathrm{L}$ pada cairan ekstrasel dan memiliki fungsi yang berlawanan dengan natrium $\left(\mathrm{Na}^{+}\right) .{ }^{6}$ Kalium sangat dibutuhkan tubuh manusia dalam jumlah sedikit, namun jika kadar kalium dalam darah berkurang dapat menyebabkan beberapa gangguan dalam tubuh, seperti gangguan gastrointestinal, gangguan sistim kardiovaskuler dan gangguan metabolisme. Jika kadar kalium mengalami peningkatan dapat menyebabkan beberapa gangguan seperti kelemahan otot, penurunan kesadaran dan kelumpuhan otot atau sistem pernapasan. ${ }^{4}$

Nilai kadar kalium dalam darah dapat berubah pada saat melakukan aktivitas fisik. Hutchinston et al. ${ }^{7}$ meneliti 30 orang dewasa sehat dengan usia rata-rata 23-63 tahun menemukan bahwa 29 dari 30 orang mengalami peningkatan kadar kalium darah setelah melakukan jogging selama 30-45 menit. Medbo et al. ${ }^{8}$ dalam penelitiannya terhadap 10 pelari jarak jauh dan 10 pelari jarak dekat menemukan bahwa terjadi peningkatan kadar kalium darah yang sangat bermakna pada saat melakukan treadmill, dan setelah melakukan treadmill kadar kalium darah mengalami sedikit penurunan dari nilai sebelum melakukan aktivitas fisik. Vollestad et al. $^{9}$ dalam penelitiannya pada 10 orang laki-laki yang sehat menemukan bahwa terjadi penurunan pada kadar kalium darah setelah berolahraga sepeda selama 10 menit.

Berdasarkan uraian di atas, penulis tertarik untuk meneliti perbandingan kadar kalium darah sebelum dan sesudah melakukan aktivitas fisik intensitas berat.

\section{METODE PENELITIAN}

Jenis penelitian ini eksperimental dengan rancangan one group pretest posttest design. Penelitian ini dilakukan di lapangan futsal Megamas, kawasan Boulevard Manado dan pemeriksaan darah dilakukan di laboraturium Prodia. Responden ialah mahasiswa Fakultas Kedokteran Universitas Sam Ratulangi Program Studi Pendidikan Dokter Umum angkatan 2011 sejumlah 21 orang. Instrumen penelitian ialah spuit injeksi 5 $\mathrm{mL}$, tourniquet, handscoen, stopwatch, tabung ethylene diamine tetraacetic acid (EDTA), cool box ice pack, AVL 9180 electrolite analyzer, alkohol 70\%, kapas, dan plester. Data yang diperoleh kemudian diolah dan dianalisis menggunakan program SPSS dan dianalisis menggunakan uji t berpasangan (paired t-test).

\section{HASIL PENELITIAN}

Responden penelitian ini berjumlah 30 orang mahasiswa berjenis kelamin laki- 
laki. Tiga orang tidak hadir dalam penelitian dan enam orang tidak ada hasil pemeriksaan laboratorium, sehingga jumlah responden yang digunakan dalam penelitian ini yaitu 21 orang. Sepuluh orang $(47,6 \%)$ dari 21 responden berusia 20 tahun, delapan orang $(38,1 \%)$ berusia 21 tahun, dan tiga orang $(14,3 \%)$ berusia 22 tahun.

Nilai kadar kalium serum normal pada manusia yaitu antara $3.5 \mathrm{mmol} / \mathrm{L}$ - 5.0 $\mathrm{mmol} / \mathrm{L}^{4}$ Pada penelitian ini hasil yang didapat yaitu: kadar kalium serum sebelum aktivitas fisik yang normal sebanyak 80,95\% (17 orang) dan yang kurang dari normal (hipokalemi) sebanyak 19,05\% (empat orang). Setelah aktivitas fisik kadar kalium normal yang ditemukan sebanyak 90,5\% (19 orang) dan yang kurang dari normal (hipokalemi) sebanyak 9,5\% (dua orang).

\section{Analisis univariat}

Hasil pemeriksaan kadar kalium serum sebelum aktivitas fisik intensitas berat didapatkan nilai maksimum 4,2 $\mathrm{mmol} / \mathrm{L}$, minimum 3,2 mmol/L, median 3,7 $\mathrm{mmol} / \mathrm{L}$, mean $3,7 \mathrm{mmol} / \mathrm{L}$ dengan standar deviasi 0,27. Hasil pemeriksaan kadar kalium serum sesudah aktivitas fisik intensitas berat didapatkan nilai maksimum 4,7 mmol/L, minimum 3,1 mmol/L, median $3,9 \mathrm{mmol} / \mathrm{L}$, mean $3,8 \mathrm{mmol} / \mathrm{L}$ dengan standar deviasi 0,42.

\section{Analisis bivariat}

Data hasil pemeriksaan kalium serum yang didapat dianalisis menggunakan uji statistik. Uji normalitas data menggunakan Shapiro-Wilk didapatkan hasil kalium serum sebelum latihan $p=0,358$ dan sesudah latihan $p=0,274$. Berdasarkan hasil uji normalitas data menggunakan Shapiro-wilk, didapatkan data kalium serum sebelum dan sesudah aktivitas fisik intensitas berat berdistribusi normal. Uji t berpasangan (paired t-test) dengan tingkat signifikan $\mathrm{p}<0,05$ diperoleh hasil $\mathrm{p}>0.05$ $(p=0,061)$. Hasil uji ini menolak H1 dan menerima $\mathrm{H} 0$ yaitu tidak terdapat perbedaan kadar kalium serum sebelum dan sesudah aktivitas fisik intensitas berat.

\section{BAHASAN}

Dari hasil penelitian ini menunjukkan tidak terdapat perbedaan bermakna antara kadar kalium serum sebelum dan sesudah aktivitas fisik intensitas berat. Faktor yang dapat menyebabkan kadar kalium serum tidak mengalami perubahan yang cukup signifikan yaitu aklimatisasi. Aklimatisasi adalah suatu proses penyesuaian diri secara psikologis dan fisiologis terhadap suatu lingkungan dengan stres yang dominan. ${ }^{10}$ Hal ini sering terjadi pada orang-orang yang biasa melakukan aktivitas fisik secara rutin (atlet). Proses aklimatisasi ini terjadi pada kelenjar keringat sehingga keringat yang dikeluarkan tidak begitu banyak saat melakukan aktivitas. Aklimatisasi kelenjar keringat merupakan akibat dari peningkatan sekresi aldosteron oleh korteks adrenal. $^{11}$

Hasil penelitian ini berbeda dengan penelitian terdahulu dimana terdapat perbedaan antara kadar kalium serum sebelum dan sesudah aktivitas fisik intensitas berat. Penelitian yang dilakukan oleh Hutchinston et al. ${ }^{7}$ yang dilakukan pada 30 orang (usia rata-rata 23-63 tahun) menemukan bahwa 29 dari 30 orang mengalami peningkatan kadar kalium darah setelah melakukan jogging selama 30-45 menit. Penelitian yang dilakukan oleh AlNawaiseh et al. ${ }^{12}$ pada 10 orang atlet lari dari Yordania menemukan bahwa terjadi peningkatan kadar kalium setelah melakukan treadmill selama 15 menit pertama dalam ruang yang sudah dirancang untuk mengontrol panas dan kelembaban selama latihan. Penelitian yang dilakukan oleh Meludu et al. ${ }^{13}$ pada delapan orang laki-laki usia \pm 22 tahun dengan Indeks Massa Tubuh (IMT) $\pm 23 \quad \mathrm{~kg} / \mathrm{m}^{2}$ menemukan bahwa terjadi peningkatan kadar kalium darah setelah berolahraga sepeda ergometer selama tiga menit dengan frekuensi pedal 90 putaran per menit.

Peningkatan kadar kalium serum ini dapat terjadi ketika melakukan aktivitas fisik, karena terjadi perpindahan kalium dari dalam cairan intrasel (CIS) ke cairan 
ekstrasel (CES). Perpindahan kaliaum dari intrasel ke ekstrasel ini terjadi karena ketika beraktivitas, kalium pada cairan ekstrasel dikeluarkan bersama-sama dengan keringat sebagai akibat dari peningkatan panas tubuh, dan untuk menjaga kadar kalium pada ekstrasel maka kalium dari intrasel berpidah ke ekstrasel. ${ }^{4}$

Hasil penelitian ini juga berbeda dengan penelitian yang dilakukan oleh Medbo et al. ${ }^{8}$ terhadap 10 pelari jarak jauh dan 10 pelari jarak dekat. Medbo et al. menemukan bahwa setelah melakukan treadmill kadar kalium darah mengalami sedikit penurunan dari nilai sebelum melakukan aktivitas fisik. Sama halnya dengan Medbo, Vollestad et al. $^{9}$ dalam penelitiannya pada 10 orang laki-laki yang sehat menemukan bahwa terjadi penurunan pada kadar kalium darah setelah berolahraga sepeda selama 10 menit. Hasil dari penelitian ini juga berbeda dengan penelitian yang dilakukan oleh Nielsen et al. ${ }^{14}$ pada enam orang laki-laki dengan usia \pm 25 tahun dan tinggi badan $\pm 185 \mathrm{~cm}$ menemukan bahwa terjadi penurunan kadar kalium darah 2.2 menit setelah melakukan aktivitas kayuhan sebanyak 60 kali per menit dengan posisi terlentang pada ergometer, penelitian ini dilakukan selama 32 sesi latihan (satu sesi 5 menit) dalam 7 minggu.

Keterbatasan penelitian ini ialah jumlah responden yang sedikit yaitu 21 orang dan kurang dari target yang telah ditentukan sebelumnya yaitu sebanyak 30 orang. Hal ini disebabkan karena populasi dari responden ialah mahasiswa Fakultas Kedokteran Universitas Sam Ratulangi Manado yang sebagian sedang dalam Kuliah Kerja Nyata (KKN) sehingga tiga orang responden menggundurkan diri dan enam orang responden tidak ada hasil laboratorium..

\section{SIMPULAN}

Berdasarkan penelitian ini disimpulkan bahwa tidak terdapat perbedaan bermakna antara kadar kalium serum sebelum dan sesudah melakukan aktivitas fisik intensitas berat.

\section{SARAN}

1. Perlu memperhatikan intensitas, durasi, frekuensi dan jenis kegiatan olahraga yang akan dilakukan sesuai dengan umur dan tujuan yang akan dicapai.

2. Penting untuk mengonsumsi buah dan sayur-sayuran yang kaya kalium agar kadar kalium serum terjaga dalam batas normal.

\section{DAFTAR PUSTAKA}

1. Budiman C. Ilmu kedokteran pencegahan komunitas. Jakarta: EGC, 2006.

2. Sjostrom M, Ekelund U, Yngve A. Pengkajian aktivitas fisik. In: Gibney MJ, Margetts BM, Kearney JM, Arab L, editors. Gizi kesehatan masyarakat. Hartono A, alih bahasa. Jakarta: EGC, 2009; p. 101-6.

3. Wiarto G. Fisiologi dan olahraga, Yogyakarta: Graha Ilmu, 2013; p, 1-3, 115- 6, 139- 43.

4. Grober U. Mikro nutrient: Penyelarasan metabolik, pencegahan dan terapi. Hadinata AH, Nurul A, alih bahasa. Jakarta: EGC, 2009; p. 104-6.

5. Mulyono. Kamus Kimia. Jakarta: Bumi Angkasa, 2009; p. 207-9.

6. Murray RK, Granner DK. Biokimia komunikasi ekstrasel dan intrasel. In: Murray RK, Granner DK, Rodwell VW, editors. Biokimia Harper (27th ed). Pendit BU, alih bahasa. Jakarta: EGC, 2006; p. 436, 448-9.

7. Hutchinson RG, Barsdale B, Watson RL. The effects of exercise on serum potassium levels. Ann Intern Med. 1992;101:398-400.

8. Medbo JI, Sejersted OM. Plasma potassium changes with high intencity exercise. Ann Intern Med. 1990;421:105-22.

9. Vollestad NK, Hallen J, Sejersted OM. Effect of exercise intensity on potassium balance in muscle and blood of man. Ann Intern Med. 1994;2250: 359-88.

10. Mazess RB. Biological adaptation: Aptitudes and acclimatitation. The Hague: Mouton Publishers. 1975; p. 918.

11. Wendt D, van loon LJC, van Marken Lichtenbelt WD. Thermoregulatin during exercise in the heat. Sport med. 
Jurnal e-Biomedik (eBm), Volume 3, Nomor 3, September-Desember 2015

2007;37(8):669-82.

12. Al-Nawaiseh A, Batainefh $\mathbf{M}, \quad$ Al Nawayseh AH, Alsuod $\mathrm{H}$. Physiological Responses of Distance Runners During Normal and Warm Condition. Journal of Exercise Physiology online. 2013;16(Pt 2):1-11.

13. Meluda SC, Nishimuta M, Yoshitake Y, Toyooka F, Kodama N, Kim CS, et al. Anaerobic exercise induced changes in serum mineral concentrations. African Journal of Biomedical. 2002;5:13-7.

14. Nielsen JJ, Mohr M, Klarskov C, Kristensen M, Krustrup P, Juel C, et al. Effects of high-intensity intermittent training on potassium kinetics and performance in human skeletal muscle. The Physiological Society. J physiol. 2003;554.3:857-70. 